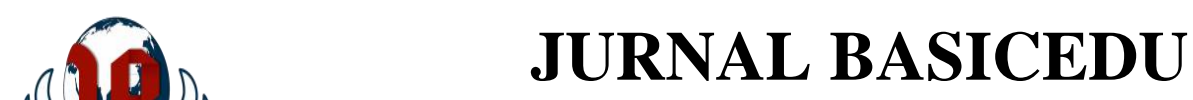

Volume 5 Nomor 3 Tahun 2021 Halaman 1149 - 1160

Research \& Learning in Elementary Education https://jbasic.org/index.php/basicedu

\title{
Efektivitas Model Pembelajaran Problem Based Learning dan Problem Solving terhadap Kemampuan Berpikir Kritis Siswa Sekolah Dasar
}

\author{
Oktavia Wahyu Ariyani $^{1 凶}$, Tego Prasetyo ${ }^{2}$ \\ Universitas Kristen Satya Wacana, Indonesia ${ }^{1,2}$ \\ E-mail:292017015@ student.uksw.edu ${ }^{1}$,tego.prasetyo@uksw.edu ${ }^{2}$
}

\begin{abstract}
Abstrak
Kemampuan berpikir kritis dilaksanakan saat proses belajar berlangsung. Namun pada kenyataannya kemampuan berpikir kritis pada siswa masih tergolong sangat rendah. Penelitian ini bertujuan untuk mengetahui efektivitas model pembelajaran Problem Based Learning dan Problem Solving terhadap kemampuan berpikir kritis pada pembelajaran tematik siswa kelas IV SD. Penelitian ini menggunakan jenis penelitian meta analisis. Pengumpulan data dilakukan melalui pencarian artikel-artikel di Google Cendekia. Dari hasil pencarian artikel di Google Cendekia didapatkan 20 artikel yang konkret. Uji hipotesis menggunakan uji ancova yang menunjukkan f hitung $>\mathrm{f}$ tabel yaitu 3,462 > 3,20 dan signifikasinya $0,079>0,05$ yang berarti $\mathrm{H}_{\mathrm{o}}$ ditolak dan $\mathrm{H}_{\mathrm{a}}$ diterima, artinya terdapat perbedaan yang signifikan dalam menggunakan model pembelajaran Problem Based Learning dan Problem Solving dalam kemampuan berpikir kritis pada pembelajaran tematik siswa kelas IV SD. Hasil analisis Effect Size menggunakan uji ancova pada model pembelajaran Problem Based Learning dan Problem Solving diperoleh hasil Correct Model yang diketahui Partical eta Squared sebesar 0,161 dengan nilai signifikasi 0,079 yang berarti model pembelajaran Problem Based Learning dan Problem Solving memberikan pengaruh yang tergolong kecil. Berdasarkan pengolahan data, maka dapat disimpulkan bahwa model pembelajaran Problem Based Learning lebih efektif dibandingkan dengan menggunakan model pembelajaran Problem Solving untuk kemampuan berpikir kritis pada pembelajaran tematik siswa kelas IV SD.
\end{abstract}

Kata Kunci: problem based learning, problem solving, kemampuan berpikir kritis siswa SD.

\begin{abstract}
Critical thinking skills are implemented during the learning process. However, in reality, students' critical thinking skills are still very low. This study aims to determine the effectiveness of Problem Based Learning and Problem Solving learning models on critical thinking skills in thematic learning of fourth grade elementary school students. This study is a metaanalysis research. The data was collected by searching for articles on Google Cendekia. From the search results for articles on Google Cendekia, 20 concrete articles were found. Hypothesis testing uses the ANCOVA test which shows $f$ count $>f$ table, namely 3.462> 3.20 and the significance is 0.079>0.05, which means that $H_{o}$ is rejected and $H_{a}$ is accepted, meaning that there is a significant difference in using the Problem Based Learning and Problem Solving learning model on students' critical thinking skills in thematic learning of fourth grade elementary school. The results of the Effect Size analysis using the ANCOVA test on the Problem Based Learning and Problem Solving learning models obtained the Correct Model results which are known to be Partical eta Squared of 0.161 with a significance value of 0.079, which means that the Problem Based Learning and Problem Solving learning models have a relatively small effect. Based on data processing, it can be concluded that the Problem Based Learning model is more effective than using the Problem Solving learning model for students' critical thinking skills in thematic learning of grade IV SD.
\end{abstract}

Keywords: problem based learning, problem solving, critical thinking skills of elementary students.

Copyright (c) 2021 Oktavia Wahyu Ariyani, Tego Prasetyo

Corresponding author :

Email:292017015@student.uksw.edu

DOI : https://doi.org/10.31004/basicedu.v5i3.892

ISSN 2580-3735 (Media Cetak)

ISSN 2580-1147 (Media Online)

Jurnal Basicedu Vol 5 No 3 Tahun 2021

p-ISSN 2580-3735 e-ISSN 2580-1147 
1150 Efektivitas Model Pembelajaran Problem Based Learning dan Problem Solving terhadap Kemampuan Berpikir Kritis Siswa Sekolah Dasar - Oktavia Wahyu Ariyani, Tego Prasetyo

DOI : https://doi.org/10.31004/basicedu.v5i3.892

\section{PENDAHULUAN}

Pendidikan sangatlah penting untuk pembangunan dan merupakan kunci pembentukan suatu bangsa dan negara. Kesuksesan dari pendidikan yaitu mencapai tujuan pendidikan nasional, salah satu faktor keberhasilan pendidikan bergantung pada proses pembelajaran di dalam kelas yang diciptakan oleh guru kelas. Selain guru yang berperan dalam proses pembelajaran di dalam kelas, siswa juga berperan aktif dalam terlaksananya pembelajaran. Sistem pendidikan khususnya di Indonesia saat ini menggunakan Kurikulum 2013 atau yang sering disebut dengan K13. Sistem pendidikan di Indonesia yang dahulunya guru menjadi pusat para siswa, dengan metode ceramah dan siswa mendengarkan, menyimak serta menulis, siswa tidak diberi kesempatan untuk mencari tahu informasi materi pelajaran dan tidak dilatih diberikan masalah mengenai materi pembelajaran. Siswa sebelum perubahan sistem kurikulum 2013 pada kenyataannya kurang terampil dalam kemampuan berpikir kritis, berpikir kreatif, berkolaborasi, dan berkomunikasi.

Pembelajaran tematik adalah salah satu model pembelajaran terpadu atau kurikulum 2013 yang mengaitkan beberapa mata pelajaran dengan maksud memberikan pengalaman bermakna bagi peserta didik yang diatur dalam (Permendikbud Nomor 22 Tahun 2016) tentang Standar Proses. Menurut (Rusman, 2013:254), pembelajaran tematik adalah model pembelajaran terpadu dengan melibatkan beberapa mata pelajaran menggunakan pendekatan tematik untuk memberikan pengalaman yang bermakna bagi siswa. Salah satu model pembelajaran yang dapat mengembangkan kemampuan berpikir kritis adalah menggunakan model pembelajaran Problem Based Learning. (Suparman, 2016:84)), problem based learning adalah model stategi pembelajaran yang peserta didiknya secara kolaboratif memecahkan masalah dan merefleksikan pengalaman. Ciri-ciri Problem Based Learning menurut (Amir, 2012:12) yaitu Problem Based Learniing dimulai dengan guru memberikan masalah kepada siswa yang berkaitan dengan kehidupan sehari-hari atau kehidupan nyata, pembelajaran selanjutnya secara berkelompok dan merumuskan masalah serta mengidentifikasi menurut pengetahuan masing-masing, siswa mempelajari, mencari materi, dan mencari solusi dari suatu masalah. Proses mencari materi dan mencari solusi ini bertujuan untuk melatih siswa meningkatkan kemampuan berpikir kritis. Model pembelajaran Problem Based Learning memang dirancang untuk membantu siswa mengembangkan kemampuan berpikir kritis, memecahkan masalah serta menjadikan siswa mandiri dalam belajar.

Menurut (Utomo Dananjaya, 2013:129), metode problem solving yaitu upaya peningkatan hasil melalui proses secara ilmiah untuk menilai, menganalisis, dan memahami keberhasilan. Model pembelajaran Problem Solving melatih siswa untuk mncari informasi dan mengecek validitas informasi dari sumber lain. Problem Solving diharapkan dapat memberikan perubahan pola berpikir siswa agar memperhatikan dan mampu menganalisa suatu masalah yang selanjutnya dapat dipecahkan dengan baik. Problem Solving di anggap cocok untuk menyelesaikan masalah pembelajaran karena melatih cara berpikir dan bernalar dalam menarik kesimpulan, mengembangkan kemampuan memecahkan masalah dengan menyampaikan informasi.

Menurut (Jensen, 2011:195), berpikir kritis berarti proses mental yang efektif dan handal, digunakan dalam mengejar pengetahuan yang relevan dan benar tentang dunia. Menurut (Santrock, 2011:359), pemikiran kritis adalah pemikiran reflektif dan produktif, serta melibatkan evaluasi bukti. Kemampuan siswa untuk berpikir kritis dilaksanakan saat proses belajar berlangsung, dengan guru memberikan arah kepada siswa untuk menyelesaikan permasalahan yang sudah disediakan guru. Namun pada kenyataannya berpikir kritis sangat rendah, sebab kurangnya pengetahuan dapat mempengaruhi cara berpikir siswa karena hanya berfokus pada aspek mengingat dan memahami. Berpikir kritis sangatlah penting bagi setiap manusia dalam menyikapi permasalahan yang ada dalam kehidupan nyata yang tidak bisa untuk dihindarkan. Dengan berpikir kritis dapat membuat seseorang untuk menyesuaikan, mengubah, mengatur, dan memperbaiki pikiran, sehingga dapat mengambil keputusan yang lebih tepat. Menurut (Sapriya, 2011:87), tujuan berpikir kritis adalah untuk 
1151 Efektivitas Model Pembelajaran Problem Based Learning dan Problem Solving terhadap Kemampuan Berpikir Kritis Siswa Sekolah Dasar - Oktavia Wahyu Ariyani, Tego Prasetyo DOI : https://doi.org/10.31004/basicedu.v5i3.892

mencoba atau menjajal gagasan dan masukan, termasuk dalam melaksanakan penilaian atau pandangan yang didasari oleh gagasan yang dikemukakan.

Penelitian yang dilakukan oleh Tri Puji Ati, Yohana Setiawan (2020) dalam jurnalnya yang berjudul "Efektivitas Problem Based Learning-Problem Solving Terhadap Kemampuan Kritis dalam Pembelajaran Matematika Siswa Kelas V". Dari hasil penelitiannya diperoleh bahwa model pembelajaran Problem Based Learning lebih efektif dari pada Probem Solving dalam mengukur kemampuan berpikir kritis pada pembelajaran matematika siswa kelas V. Selanjutnya, penelitian yang dilakukan oleh (Yudi Cahyo \&Tego Prasetyo, 2020) dalam jurnalnya yang berjudul "Efektivitas Model Problem Based Learning dan Discovery Learning terhadap kemampuan berpikir kritis siswa Sekolah Dasar". Berdasarkan hasil penelitian kelas eksperimen 1 dengan menggunakan model pembelajaran Problem Based Learning mendapatkan nilai 74,6 yang menunjukkan bahwa siswa mampu berpikir kritis. Kemudian penelitian yang dilakukan oleh (Anastasia Nandhita, 2018) Penerapan model pembelajaran Problem Based Learning dapat meningkatkan kemampuan berpikir kritis dan hasil belajar siswa dalam menyelesaikan soal cerita pada mata pelajaran matematika kelas 4 SD Negeri Suruh 01. Persentase jumlah siswa yang mencapai KKM meningkat dari kondisi awal 44,84\%, meningkat menjadi 69,44\% pada evaluasi siklus I dan menjadi 88,89\% pada evaluasi siklus II. Penelitian yang dilakukan (Ayudya \& Rahayu, 2020) bahwa model pembelajaran Problem Based Learning lebih efektif dibandingkan model pembelajaran Think Pair Share. Dapat dilihat dari hasil nilai rata-rata skor posttes siswa dengan menggunakan model Problem Based Learning mendapatkan nilai rata-rataa sebesarr 88,6 dengan NGain mengalami peningkatan sebesar 0,67. Sedangkan rata-rata nilai yang menggunakan model Think Pair Share memperoleh nilai skornya 82,4 dengan nilai NGainnya mengalami peningkatan sebesar 0,54.

Berdasarkan uraian latar belakang diatas, beberapa penelitian menyatakan serta menyimpulkan bahwa hasil penelitian tentang model pembelajaran Problem Based Learning lebih efektif untuk digunakan dibandingkan dengan model pembelajaran problem solving. Dalam proses mengembangkan kemampuan berpikir kritis siswa, penulis tertarik untuk mengujicobakan dan membuktikan apakah benar model pembelajaran Problem Based Learning lebih efektif dari Problem Solving terhadap kemampuan berpikir kritis terhadap mata pelajaran tematik kelas IV SD. Berdasarkan pernyataan diatas penulis melakukan penelitian meta analisis "Efektivitas Model Pembelajaran Problem Based Learning dan Problem Solving Terhadap Kemampuan Berpikir Kritis Pada Pembelajaran Tematik Siswa Kelas IV SD”. Penelitian ini dilakukan untuk mengetahui efektivitas model pembelajaran Problem Based Learning dan Problem Solving terhadap kemampuan berpikir kritis pada pembelajaran tematik siswa kelas IV SD. Penelitian ini dilakukan dalam kondisi covid-19 sehingga penelitian ini memiliki perbedaan dari penelitian sebelumnya yakni menggunakan metode meta analisis dikarenakan adanya wabah global yang sedang terjadi yaitu covid 19 (corona) dengan hasil penelitian dalam bentuk menganalisis artikel yang sudah ditemukan.

\section{METODE PENELITIAN}

Penelitian ini dilakukan untuk mengetahui efektivitas model pembelajaran Problem Based Learning dan Problem Solving terhadap kemampuan berpikir kritis pada pembelajaran tematik siswa kelas IV SD. Penelitian ini menggunakan jenis penelitian meta analisis. Menurut (Kadir, 2017:165) meta analisis adalah suatu analisis integrative hasil penelitian dengan fokus atau tema yang sama. Pengumpulan data dilakukan melalui pencarian artikel-artikel di Google Cendekia menggunakan kata kunci "Problem Based Learning", "Problem Solving", dan "kemampuan berpikir kritis" yang terbit pada tahun 2013 sampai tahun 2020 serta dibatasi hanya menggunakan artikel dari jurnal yang sudah terakreditasi sinta minimal sinta 5. Dari hasil pencarian artikel di Google Cendekia didapatkan 20 artikel yang konkret dari berbagai jurnal yang telah terakreditasi sinta minimal sinta 5. Data berupa 20 artikel yang telah didapatkan, kemudian dianalisis untuk mengetahui tingkat keefetifan model pembelajaran terhadap kemampuan berpikir kritis siswa. Analisis data 
1152 Efektivitas Model Pembelajaran Problem Based Learning dan Problem Solving terhadap Kemampuan Berpikir Kritis Siswa Sekolah Dasar - Oktavia Wahyu Ariyani, Tego Prasetyo

DOI : https://doi.org/10.31004/basicedu.v5i3.892

yang digunakan dalam penelitian ini menggunakan uji prasyarat yaitu uji normalitas, uji homogenitas, dan uji linearitas. Setelah melakukan uji prasyarat selanjutnya dapat dilakukan uji Ancova dengan menggunakan SPSS 24.00 for windows. Uji Ancova dilakukan untuk mengetahui apakah ada perbedaan antara model pembelajaran Problem Based Learning dan Problem Solving terhadap kemampuan berpikir kritis pada pembelajaran tematik siswa SD. Setelah melakukan uji Ancova kemudian dilakukan uji hipotesis. Uji hipotesis dilakukan untuk melihat apakah hipotesis diterima atau ditolak. Effect Size menggunakan uji Ancova yang dilakukan untuk melihat perbedaan antara model pembelajaran Problem Based Learning dan Problem Solving. Teknik pengumpulan data menurut (Sugiyono, 2010:308) merupakan langkah yang paling utama dalam penelitian, karena untuk mendapatkan data yang memenuhi standar yang telah ditetapkan atau untuk memperoleh data dalam penelitian. Teknik analisis data yang digunakan adalah teknik analisis effect size. Rumus effect analisis yang digunakan adalah formula pengaruh dengan rumus eta kuadrat ( $\mathrm{n} 2)$.

\section{HASIL DAN PEMBAHASAN}

Berdasarkan hasil pencarian artikel yang sesuai dengan judul penelitian "Efektivitas Model Pembelajaran Problem Based Learning dan Problem Solving Terhadap Kemampuan Berpikir Kritis Pada Pembelajaran Tematik Siswa Kelas IV SD" diperoleh sebanyak 20 artikel yang sesuai kriteria. Artikel yang diperoleh mulai terbitan tahun 2013 sampai 2020, kemudian artikel yang diperoleh terkait model pembelajaran Problem Based Learning dan Problem Solving yakni 10 artikel tentang penelitian model pembelajaran Problem Based Learning dan 10 artikel tentang penelitian model pembelajaran Problem Solving. Berikut ini klasifikasi artikel model pembelajaran Problem Based Learning diantaranya penelitian yang dilakukan oleh Abdul Rahman, Khaeruddin, Evi Ristiana pada tahun 2020 dengan judul penelitian Pengaruh Model PBL terhadap kemampuan berpikir kritis dan pemahaman konsep IPA siswa kelas V SDN 30 Sumpanghuta yang dipublikasikan di EDUMASPUL Jurnal Pendidikan diberikan kode data A1. Selanjutnya penelitian yang dilakukan oleh Mutiara Sasy Ayudya dan Theresia Sri Rahayu pada tahun 2020 dengan judul penelitian Efektivitas model Problem Based Learning dan Think Pair Share ditinjau dari kemampuan berpikir kritis siswa kelas 5 dalam pelajaran matematika yang dipublikasikan di Jurnal Pendidikan Tambusai diberikan kode data A2. Penelitian yang dilakukan oleh Faisal Miftakhul Islam, Nyoto Harjono, Gamaliel Septian Airlanda pada tahun 2018 dengan judul penelitian Penerapan model Problem Based Learning untuk meningkatkan berpikir kritis dan hasil belajar IPA dalam Tema 8 Kelas 4 SD yang dipublikasikan di Jurnal Mitra Pendidikan diberikan kode data A3. Penelitian yang dilakukan oleh Syahroni Ejin pada tahun 2016 dengan judul Pengaruh model Problem Based Learning (PBL) terhadap pemahaman konsep dan keterampilan berpikir kritis siswa kelas IV SDN Jambu Hilir Baluti 2 pada mata pelajaran Ilmu Pengetahuan Alam yang dipublikasikan di Jurnal Jurnal Pendidikan (Teori dan Praktik) diberikan kode A4. Penelitian yang dilakukan oleh Dina Ayuningsih, Firosalia Kristin, Indri Anugraheni pada tahun 2019 dengan judul penelitian Penerapan model Problem Based Learning (PBL) untuk meningkatkan hasil belajar dan berpikir kritis matematika yang dipublikasikan di Jurnal Cakrawala Pendas diberikan kode A5. Penelitian yang dilakukan oleh Dewi Nurkhasanah, Wahyudi, Endang Indarini pada tahun 2019 dengan judul penelitian Penerapan model Problem Based Learning untuk meningkatkan kemampuan berpikir kritis siswa kelas V SD yang dipublikasikan di Jurnal Satya Widya diberikan kode A6. Penelitian yang dilakukan oleh Novi Retno Wardhani pada tahun 2018 dengan judul penelitian Pengaruh model PBL terhadap kemampuan berpikir kritis pembelajaran IPA Kelas IV SDN Kramattemenggung 2 Sidoarjo Jurnal Penelitian Pendidikan Guru Sekolah Dasar yang dipublikasikan di Jurnal Penelitian Pendidikan Guru Sekolah Dasar diberikan kode data A7. Penelitian yang dilakukan oleh Anastasia Nandhita Asriningtyas, Firosalia Kristin, Indri Anugraheni pada tahun 2018 dengan judul penelitian Penerapan model pembelajaran Problem Based Learning untuk meningkatkan kemampuan berpikir kritis dan hasil belajar matematika siswa kelas 4 SD yang dipublikasikan di JIPMat Jurnal Ilmiah 
1153 Efektivitas Model Pembelajaran Problem Based Learning dan Problem Solving terhadap Kemampuan Berpikir Kritis Siswa Sekolah Dasar - Oktavia Wahyu Ariyani, Tego Prasetyo DOI : https://doi.org/10.31004/basicedu.v5i3.892

Pendidikan Matematika diberikan kode data A8. Penelitian yang dilakukan oleh Wahyu Purnaningsih, Stefanus Christian Relmasira, Agustina Tyas Asri Hardini pada tahun 2019 dengan judul penelitian Upaya peningkatan kemampuan berpikir kritis dan hasil belajar tematik melalui model Problem Based Learning (PBL) Kelas V SD yang dipublikasikan di Jurnal Kajian Penelitan dan Pendidikan dan Pembelajaran diberikan kode data A9. Penelitian yang dilakukan oleh Khintan Ustino Alita, Henny Dewi Koeswanti, Sri Giarti pada tahun 2019 dengan judul penelitian Penerapan model Problem Based Learning untuk meningkatkan kemapuan berpikir kritis siswa kelas V SDN Ledok 5 Tahun pelajaran 2018/2019 yang dipublikasikan di Jurnal Basicedu diberikan kode data A10.

Klasifikasi artikel model pembelajaran Problem Solving diantaranya penelitian yang dilakukan oleh Sisnanto, Wahyudi, Endang Indarini pada tahun 2019 dengan judul penelitian Efektivitas model pembelajaran Problem Solving dan Group Investigation terhadap peningkatan kemampuan berpikir kritis siswa kelas 4 SD dalam pelajaran matematika yang dipublikasikan di JURNAL PAJAR (Pendidikan dan Pengajaran) diberikan kode data B1. Selanjutnya penelitian yang dilakukan oleh I Nyoman Budiana, Dewa Nyoman Sudana, Ign I Wayan Suwatra pada tahun 2013 dengan judul penelitian Pengaruh model Creative Problem Solving (CPS) terhadap kemampuan berpikir kritis siswa pada pelajaran IPA siswa kelas V SD yang dipublikasikan JURNAL MIMBAR PGSD UNDIKSHA diberikan kode data B2. Penelitian yang dilakukan oleh Maulid Anwar Sidiq, Tego Prasetyo pada tahun 2020 dengan judul penelitian Efektivitas model pembelajaran Problem Solving dan Discovery Learning terhadap kemampuan berpikir kritis siswa sekolah dasar yang dipublikasikan di Jurnal Basicedu diberikan kode data B3. Penelitian yang dilakukan oleh Wahyu wulandari, Wahyudi pada tahun 2020 dengan judul penelitian Efektivitas model pembelajaran Problem Solving dan Problem Posing ditinjau dari kemampuan berpikir kritis matematika siswa kelas 4 yang dipublikasikan di JSD : Jurnal Sekolah Dasar diberikan kode data B4. Penelitian yang dilakukan oleh Yohana Setiawan, Nathania Tri Asih Pattiasna pada tahun 2019 dengan judul penelitian Peningkatan hasil belajar dan berpikir kritis dengan menggunakan metode Problem Solving pada siswa kelas IV SD Negeri Mangunsari 01 yang dipublikasikan di Jurnal Pendidikan Tambusai yang diberikan kode data B5. Penelitian yang dilakukan oleh Elva Pristy Afifah, Wahyudi, Yohana Setiawan pada tahun 2019 dengan judul penelitian Efektivitas Problem Based Learning dan Problem Solving terhadap kemampuan berpikir kritis siswa kelas V dalam pembelajaran matematika yang dipublikasikan di MUST Journal of Mathematics Education, Science and Technology diberikan kode data B6. Penelitian yang dilakukan oleh Metta Ariyanto, Firosalia Kristin, Indri Anugraheni pada tahun 2018 dengan judul penelitian Penerapan model pembelajaran Problem Solving untuk meningkatkan kemampuan berpikir kritis dan hasil belajar siswa yang dipublikasikan di JGK (Jurnal Guru Kita) diberikan kode data B7. Penelitian yang dilakukan oleh Ni Luh Mita Sri Mahendra Yanti pada tahun 2017 dengan judul penelitian Pengaruh model pembelajaran Creative Problem Solving berbasis educative games terhadap kemampuan berpikir kritis dan hasil belajar IPA kelas IV di Gugus IV Kecamatan Kuta, Kabupaten Badung yang dipublikasikan di Jurnal Ilmiah Pendidikan \& Pengajaran diberikan kode data B8. Penelitian yang dilakukan oleh Evi Eriyanti pada tahun 2018 dengan judul penelitian Pengaruh model CPS terhadap kemampuan berpikir kritis pembelajaran IPA kelas IV SD Kemuning Tarik Sidoarjo yang dipublikasikan di Jurnal Penelitian Guru Sekolah Dasar diberikan kode data B9. Penelitian yang dilakukan oleh Hendriana Monalisa, Nyoto Harjono pada tahun 2020 dengan judul penelitian Komparasi model pembelajaran Problem Based Learning dan Problem Solving ditinjau dari pengaruhnya terhadap pencapaian kemampuan berpikir kritis pada mupel IPA Siswa SD Kelas V yang dipublikasikan di PIONIR Jurnal Pendidikan diberikan kode data B10.

Data artikel yang diperoleh diolah dengan cara menyimpulkan antara model Problem Based Learning dan Problem Solving. Hasil komparasi model pembelajaran Problem Based Learning dan Problem Solving sebagai berikut. 
1154 Efektivitas Model Pembelajaran Problem Based Learning dan Problem Solving terhadap Kemampuan Berpikir Kritis Siswa Sekolah Dasar - Oktavia Wahyu Ariyani, Tego Prasetyo DOI : https://doi.org/10.31004/basicedu.v5i3.892

Tabel 1

Presentase peningkatan model Problem Based Learning siswa

\begin{tabular}{|c|c|c|c|c|}
\hline \multirow{2}{*}{ No } & \multirow{2}{*}{$\begin{array}{c}\text { Kode } \\
\text { Data }\end{array}$} & Pretest & Presentase \% & Peningkatan \\
\cline { 3 - 5 } & & & & \\
\hline 1 & A1 & 50,1 & 79,7 & 29,6 \\
\hline 2 & A2 & 64,3 & 88,6 & 24.3 \\
\hline 3 & A3 & 71,8 & 89,6 & 17,8 \\
\hline 4 & A4 & 67,0 & 83,5 & 16,5 \\
\hline 5 & A5 & 62,3 & 77,0 & 14,7 \\
\hline 6 & A6 & 58,98 & 97,4 & 38,42 \\
\hline 7 & A7 & 51,93 & 82,09 & 30,16 \\
\hline 8 & A8 & 60,82 & 74,21 & 13,39 \\
\hline 9 & A9 & 58,57 & 76,19 & 17,62 \\
\hline 10 & A10 & 41,0 & 75,0 & 34,0 \\
\hline & Mean & $\mathbf{5 8 , 6 8}$ & $\mathbf{8 1 , 3 2}$ & $\mathbf{2 3 , 6 4}$ \\
\hline
\end{tabular}

Tabel 2

Presentase peningkatan model Problem Solving siswa

\begin{tabular}{|c|c|c|c|c|}
\hline \multirow{2}{*}{ No } & \multirow{2}{*}{$\begin{array}{c}\text { Kode } \\
\text { Data }\end{array}$} & Pretest & Presentase \% & Posttest \\
\cline { 3 - 5 } & & & & \\
\hline 1 & B1 & 81,0 & 86,0 & 5,0 \\
\hline 2 & B2 & 33,45 & 45,45 & 12,0 \\
\hline 3 & B3 & 60,36 & 75,6 & 15,24 \\
\hline 4 & B4 & 64,67 & 79,76 & 15,09 \\
\hline 5 & B5 & 70,0 & 72,0 & 2,0 \\
\hline 6 & B6 & 61,94 & 80,44 & 18,5 \\
\hline 7 & B7 & 71,12 & 80,5 & 9,38 \\
\hline 8 & B8 & 32,84 & 47,05 & 14,21 \\
\hline 9 & B9 & 70,32 & 86,93 & 16,61 \\
\hline 10 & B10 & 61,10 & 72,03 & 10,93 \\
\hline & Mean & $\mathbf{6 0 , 6 8}$ & $\mathbf{7 2 , 5 7}$ & $\mathbf{1 1 , 8 9}$ \\
\hline
\end{tabular}

Hasil presentase pada tabel 2. presentase peningkatan model Problem Based Learning menunjukkan bahwa model pembelajaran Problem Based Learning mampu meningkatkan kemampuan berpikir kritis pada siswa Sekolah Dasar. Presentase rata-rata peningkatan pada model pembelajaran Problem Based Learning nilai terendah 13,39 dan nilai tertinggi 38,42 dengan nilai rata-rata 23,64. Presentase rata-rata model pembelajaran Problem Solving nilai terendah 2,0 dan nilai tertinggi 18,5 dengan nilai rata-rata 11,89. Menunjukkan bahwa nilai presentase model pembelajaran Problem Based Learning lebih tinggi dibandingkan dengan model pembelajaran Problem Solving.

Berdasarkan dari hasil presentase model pembelajaran Problem Based Learning lebih tinggi daripada menggunakan model pembelajaran Problem Solving. Hal ini ditunjukkan dari hasil komparasi sebagai berikut. 
1155 Efektivitas Model Pembelajaran Problem Based Learning dan Problem Solving terhadap Kemampuan Berpikir Kritis Siswa Sekolah Dasar - Oktavia Wahyu Ariyani, Tego Prasetyo DOI : https://doi.org/10.31004/basicedu.v5i3.892

Tabel 3

\begin{tabular}{|c|c|c|c|}
\hline \multirow{2}{*}{ Pengukuran } & \multicolumn{2}{|c|}{ Rata-rata skor (Mean) } & \multirow{2}{*}{ Selisih } \\
\cline { 2 - 3 } & Pretest & Posttest & \\
\hline PBL & 58,68 & 81,32 & 23,64 \\
\hline$P S$ & 60,68 & 72,54 & 11,89 \\
\hline
\end{tabular}

Komparasi hasil model pembelajaran Problem Based Learning dan Problem Solving

Hasil dari pengukuran rata-rata pada tabel menunjukkan selisih rata-rata skor pada model pembelajaran Problem Based Learning adalah 23,64 sedangkan selisih model pembelajaran Problem Solving adalah 11,89. Analisis data yang dilakukan untuk mengetahui tingkat keefetifan model pembelajaran terhadap kemampuan berpikir kritis siswa. Analisis data yang digunakan dalam penelitian ini menggunakan uji prasyarat yaitu uji normalitas, uji homogenitas, dan uji linearitas. Uji prasyarat dilakukan sebelum melakukan uji Ancova. Uji Ancova dilakukan untuk melihat hasil perbedaan model pembelajaran yang digunakan terhadap kemampuan berpikir kritis siswa.

Uji normalitas memiliki tujuan yaitu untuk menentukan apakah sumber relevan berdistribusi normal atau tidak. Uji normalitas dalam penelitian ini menggunakan SPSS 24.00 windows. Berikut tabel hasil pengujian normalitas kemampuan berpikir kritis skor pretest dan posttest pada model pembelajaran Problem Based Learning dan Problem Solving.

Tabel 4

Uji Normalitas Model Pembelajaran Problem Based Learning dan Problem Solving dengan IBM SPSS statistics viewer for windows

Tests of Normality

\begin{tabular}{lr|r|r|r|r|r|} 
& \multicolumn{3}{c}{ Kolmogorov-Smirnov } & \multicolumn{3}{c|}{ Shapiro-Wilk } \\
& Statistic & df & \multicolumn{1}{c|}{ Sig. } & Statistic & \multicolumn{1}{c}{ df } & \multicolumn{1}{c}{ Sig. } \\
\hline PRETEST_PBL & .195 & 10 & $.200^{*}$ & .966 & 10 & .848 \\
\hline POSTTEST_PBL & .160 & 10 & $.200^{*}$ & .914 & 10 & .309 \\
\hline PRETEST_PS & .197 & 10 & $.200^{*}$ & .885 & 10 & .147 \\
\hline POSTTEST_PS & .182 & 10 & $.200^{*}$ & .918 & 10 & .338 \\
\hline
\end{tabular}

Berdasarkan tabel diatas dapat disimpulkan bahwa uji normalitas kemampuan berpikir kritis skor pada pretest dan posttest dari model pembelajaran Problem Based Learning dan Problem Solving dapat diartikan jika nilai signifikasi $<0,05$ maka data tidak berdistribusi normal dan jika $>0,05$ maka data berdistribusi normal.

Uji homogenitas digunakan untuk mengetahui apakah sampel skor pada artikel yang sudah dikumpulkan dari model pembelajaran Problem Based Learning dan Problem Solving memiliki varian yang sama. Hal ini dapat dikatakan data homogen jika nilai signifikasi > 0,05 dan data tidak homogen jika nilai signignifikasi $<0,05$. Tabel uji homogenitas pada skor pretest dan posttest menggunakan SPSS 24.00 for windows. 
1156 Efektivitas Model Pembelajaran Problem Based Learning dan Problem Solving terhadap Kemampuan Berpikir Kritis Siswa Sekolah Dasar - Oktavia Wahyu Ariyani, Tego Prasetyo

DOI : https://doi.org/10.31004/basicedu.v5i3.892

Tabel 5

Uji Homogenitas skor pretest model pembelajaran Problem Based Learning dan Problem Solving

\section{Test of Homogeneity of Variances}

\begin{tabular}{l|l|l|l}
$\begin{array}{l}\text { Levene } \\
\text { Statistic }\end{array}$ & df1 & df2 & Sig. \\
\hline 1.381 & 1 & 18 & .255 \\
\hline
\end{tabular}

Tabel 5 menunjukkan hasil uji homogenitas menggunakan Levene's Text. Dalam penafsiran atau interprestasi yang dilakukan dengan memilih salah satu statistik yaitu statistik yang dilakukan dengan rata-rata (Based on Mean). Berdasarkan pada tabel diatas menunjukkan hasil nilai homogenitas pretest memperoleh nilai signifikasi 0,255 > 0,05 sehingga dapat disimpulkan bahwa model pembelajaran Problem Based Learning dan Problem Solving memiliki variansi yang sama atau homogen.

\section{Tabel 6}

Uji homogenitas posttest model pembelajaran Problem Based Learning dan Problem Solving

Test of Homogeneity of Variances

Kemampuan berpikir kritis

\begin{tabular}{|c|c|c|c|}
\hline $\begin{array}{l}\text { Levene } \\
\text { Statistic }\end{array}$ & df1 & $\mathrm{df} 2$ & Sig. \\
\hline 2.155 & 1 & 18 & .159 \\
\hline
\end{tabular}

Berdasarkan tabel 6 menunjukkan hasil uji homogenitas menggunalan Leneve's Test. Interprestasi dilakukan dengan memilih salah satu statistik, yaitu statistik yang dilakukan dengan rata-rata (Based on Mean). Nilai homogenitas dilihat dari hasil signifikasi yaitu $0,159>0,05$. Dari hasil $0,159>0,05$ dapat disimpulkan bahwa model pembelajaran Problem Based Learning dan Problem Solving memiliki variansi yang sama atau homogen.

Uji linearitas merupakan uji untuk mengetahui apakah variabel bebas menggunakan model pembelajaran Problem Based Learning dan Problem Solving terhadap variabel terikat kemampuan berpikir kritis mempunyai hubungan linear atau tidak, secara signifikan. Dalam penelitian ini menggunakan linearitas SPSS 24.00 for windows. Tabel uji linearitas skor pretest dan posttest model pembelajaran Problem Based Learning.

Tabel 7

Uji Linearitas skor pretest dan posttest model pembelajaran Problem Based Learning

\begin{tabular}{|c|c|c|c|c|c|c|c|}
\hline & & & VA Table & & & & \\
\hline & & & $\begin{array}{l}\text { Sum of } \\
\text { Squares }\end{array}$ & df & $\begin{array}{l}\text { Mean } \\
\text { Square }\end{array}$ & $\mathrm{F}$ & Sig. \\
\hline posttest * & Between & (Combined) & 509.494 & 8 & 63.687 & 16.363 & .189 \\
\hline pretest & Groups & Linearity & 102.551 & 1 & 102.551 & 26.349 & .122 \\
\hline & & $\begin{array}{l}\text { Deviation } \\
\text { from Linearity }\end{array}$ & 406.943 & 7 & 58.135 & 14.937 & .197 \\
\hline & Within G & & 3.892 & 1 & 3.892 & & \\
\hline & Total & & 513.386 & 9 & & & \\
\hline
\end{tabular}

Bedasarkan dari tabel 7 dapat disimpulkan bahwa uji linearitas skor pretest dan posttest pada model pembelajaran Problem Based Learning yang dilihat dari satu statistik, yaitu dilakukan dengan Deviation from 
1157 Efektivitas Model Pembelajaran Problem Based Learning dan Problem Solving terhadap Kemampuan Berpikir Kritis Siswa Sekolah Dasar - Oktavia Wahyu Ariyani, Tego Prasetyo DOI : https://doi.org/10.31004/basicedu.v5i3.892

Linearity. Sehingga dapat ditunjukkan dari hasil uji linearitas pretest dan posstest memperoleh signifikasi 0,197 > 0,05 yang berarti skor pretest dan posttest model pembelajaran Problem Based Learning memiliki hubungan yang linear.

Tabel 8

Uji Linearitas skor pretest dan posttest model pembelajaran Problem Solving

\begin{tabular}{|c|c|c|c|c|c|c|c|}
\hline \multicolumn{8}{|c|}{ ANOVA Table } \\
\hline & & & $\begin{array}{l}\text { Sum of } \\
\text { Squares }\end{array}$ & $\mathrm{df}$ & $\begin{array}{l}\text { Mean } \\
\text { Square }\end{array}$ & $\mathrm{F}$ & Sig. \\
\hline \multirow{5}{*}{$\begin{array}{l}\text { posttest * } \\
\text { pretest }\end{array}$} & \multirow{3}{*}{$\begin{array}{l}\text { Between } \\
\text { Groups }\end{array}$} & (Combined) & 1848.202 & 8 & 231.025 & 2.073 & .493 \\
\hline & & Linearity & .054 & 1 & .054 & .000 & .986 \\
\hline & & $\begin{array}{l}\text { Deviation from } \\
\text { Linearity }\end{array}$ & 1848.148 & 7 & 264.021 & 2.369 & .463 \\
\hline & \multicolumn{2}{|c|}{ Within Groups } & 111.452 & 1 & 111.452 & & \\
\hline & \multicolumn{2}{|l|}{ Total } & 1959.654 & 9 & & & \\
\hline
\end{tabular}

Berdasarkan pada tabel 8 dapat disimpulkan bahwa uji linearitas skor pretest dan posttest model pembelajaran Problem Solving dilihat dari satu statistik, yaitu dilakukan dengan Deviation from Linearity. Sehingga dapat ditunjukkan hasil uji linearitas pretest dan posstest memperoleh signifikasi $0,463>0,05$ yang artinya memiliki hubungan yang linear.

Berdasarkan hasil normalitas, uji homogenitas, uji linearitas, dapat disimpulkan bahwa data berdistribusi normal, homogen, dan linear. Setelah melakukan uji prasyarat selanjutnya dapat dilakukan uji Ancova dengan menggunakan SPSS 24.00 for windows. Uji Ancova dilakukan untuk mengetahui apakah ada perbedaan antara model pembelajaran Problem Based Learning dan Problem Solving terhadap kemampuan berpikir kritis pada pembelajaran tematik siswa SD. Berikut adalah tabel hasil dari analisis uji Ancova.

Tabel 9

Hasil analisis data menggunakan Uji Ancova

\section{Descriptive Statistics}

Dependent Variable: kemampuan berpikir kritis

\begin{tabular}{ll|r|r} 
Model_Pembelajaran & Mean & Std. Deviation & \multicolumn{1}{l}{ N } \\
\hline PBL & 82.3290 & 7.55267 & 10 \\
\hline PS & 72.5760 & 14.75599 & 10 \\
\hline Total & 77.4525 & 12.45760 & 20 \\
\hline
\end{tabular}

Berdasarkan hasil analisis data menggunakan uji Ancova yang dilakukan pada model pembelajaran Problem Based Learning dengan jumlah 10 artikel yang didapat dengan hasil rata-rata 82,3290. Sedangkan pada model pembelajaran Problem Solving dengan jumlah 10 artukel yang didapatkan dengan hasil rata-rata 72,5760. Dapat disimpulkan bahwa terdapat perbedaan antara model pembelajaran Problem Based Learning dan Problem Solving dilihat dari kemampuan berpikir kritis pada pembelajaran tematik. Model pembelajaran Problem Based Learning hasilnya lebih tinggi dibandingkan dengan model pembelajaran Problem Solving. 
1158 Efektivitas Model Pembelajaran Problem Based Learning dan Problem Solving terhadap Kemampuan Berpikir Kritis Siswa Sekolah Dasar - Oktavia Wahyu Ariyani, Tego Prasetyo DOI : https://doi.org/10.31004/basicedu.v5i3.892

Tabel 10

Hasil analisis Uji Ancova

Tests of Between-Subjects Effects

Dependent Variable: Kemampuan berpikir kritis

\begin{tabular}{lr|r|r|r|r|r} 
Source & $\begin{array}{c}\text { Type III Sum } \\
\text { of Squares }\end{array}$ & df & Mean Square & \multicolumn{1}{c|}{ F } & Sig. & $\begin{array}{c}\text { Partial } \\
\text { Eta } \\
\text { Squared }\end{array}$ \\
\hline Corrected Model & $475.605^{\text {a }}$ & 1 & 475.605 & 3.462 & .079 & .161 \\
\hline Intercept & 119977.795 & 1 & 119977.795 & 873.257 & .000 & .980 \\
\hline Model_Pembelajaran & 475.605 & 1 & 475.605 & 3.462 & .079 & .161 \\
\hline Error & 2473.040 & 18 & 137.391 & & & \\
\hline Total & 122926.440 & 20 & & & & \\
\hline Corrected Total & 2948.645 & 19 & & & & \\
\hline
\end{tabular}

Sesuai tabel diatas hasil uji Ancova yang t erda pat pada kolom model pembelajaran di atas dapat disimpulkan bahwa signifikasi pada kolom Sig. sebesar $0,079 . \mathrm{F}_{\text {hitung }}$ yang diperoleh adalah 3,462 dan $\mathrm{F}_{\text {tabel }}$ yang terdapat dari perolehan data diatas adalah 3,20. Nilai 3,20 didapat dengan menggunakan rumus df $2=\mathrm{n}-$ $\mathrm{k}$, df2 $=20-(2+1)$, df2 $=17$. Untuk menemukan hasil 3,20 terdapat pada $F_{\text {tabel }}$ yang disesuaikan berdasarkan jumlah sampel dikurang jumlah variabel (bebas dan terikat), sehingga ditemukanlah hasil yaitu 3,20.

Setelah melakukan uji Ancova kemudian dilakukan uji hipotesis. Uji hipotesis dilakukan untuk melihat apakah hipotesis diterima atau ditolak. Sesuai dengan perhitungan hipotesis dengan menggunakan uji Ancova melalui Univariate yang menunjukkan hasil signifikasi sebesar 0,079>0,05. Uji Ancova membuktikan $\mathrm{f}$ hitung > f tabel sehingga dapat dihasilkan 3,462 > 3,20 dan signifikasinya 0,079>0,05 yang menyatakan bahwa Ho ditolak dan Ha diterima. Dapa disimpulkan bahwa terdapat perbedaan yang signifikan antara model pembelajaran Problem Based Learning dan Problem Solving terhadap kemampuan berpikir kritis pada pembelajaran tematik siswa SD.

Effect Size menunjukkan perbedaan antara skor dari model pembelajaran Problem Based Learning dan model pembelajaran Problem Solving. Effect Size merupakan satuan standar yang dapat membandingkan antar beberapa skala yang berbeda. Interprestasi Effect Size sebagai berikut.

Tabel 11

Interprestasi Effect Size

\begin{tabular}{|c|c|}
\hline Effect Size & Interprestasi \\
\hline $0<\mathrm{d}<0,2$ & Kecil \\
\hline $0,2<\mathrm{d} \leq 0,5$ & Sedang \\
\hline $0,5<\mathrm{d} \leq 0,8$ & Besar \\
\hline $\mathrm{d}>0,8$ & Sangat Besar \\
\hline
\end{tabular}

Hasil analisis Effect Siize menggunakan uji Ancova yang dilakukan untuk melihat perbedaan antara model pembelajaran Problem Based Learning dan Problem Solving sebagai berikut: 
1159 Efektivitas Model Pembelajaran Problem Based Learning dan Problem Solving terhadap Kemampuan Berpikir Kritis Siswa Sekolah Dasar - Oktavia Wahyu Ariyani, Tego Prasetyo DOI : https://doi.org/10.31004/basicedu.v5i3.892

Tabel 12

Tests of Between-Subjects Effects

Dependent Variable: Kemampuan berpikir kritis

\begin{tabular}{lr|r|r|r|r|r} 
Source & $\begin{array}{c}\text { Type III Sum } \\
\text { of Squares }\end{array}$ & df & Mean Square & F & Sig. & $\begin{array}{c}\text { Partial } \\
\text { Eta } \\
\text { Squared }\end{array}$ \\
\hline Corrected Model & $475.605^{\mathrm{a}}$ & 1 & 475.605 & 3.462 & .079 & .161 \\
\hline Intercept & 119977.795 & 1 & 119977.795 & 873.257 & .000 & .980 \\
\hline Model_Pembelajaran & 475.605 & 1 & 475.605 & 3.462 & .079 & .161 \\
\hline Error & 2473.040 & 18 & 137.391 & & & \\
\hline Total & 122926.440 & 20 & & & & \\
\hline Corrected Total & 2948.645 & 19 & & & & \\
\hline
\end{tabular}

Berdasarkan hasil dari pada tabel 12 menunjukkan bahwa hasil effect size menggunakan uji Ancova pada kolom Corrected Model yang diketahui Partial Eta Squared sebesar 0,161 dengan nilai Sig. sebesar 0,079. Hal ini menunjukkan bahwa model pembelajaran Problem Based Learning dan Problem Solving memberikan pengaruh yang tergolong kecil.

Penelitian yang sudah dilakukan oleh (Elva Pristy Afifah, Wahyudi, 2019) membuktikan bahwa menggunakan model pembelajaran Problem Based Learning lebih efektif dibandingkan model Problem Solving. Dengan hasil pretest Problem Based Learning sebesar 64,22 dan posttest sebesar 85,83. Sedangkan hasil pretest Problem Solving sebesar 61,94 dan posttest sebesar 80,44.

Berbeda dengan penelitian sebelumnya, Penulis melakukan penelitian dalam kondisi covid-19 sehingga penelitian ini dilakukan menggunakan jenis penelitian meta analisis dengan cara menganalisis data yang diperoleh dari artikel-artikel di Google Cendekia dan tentunya artikel-artikel yang dikumpulkan sesuai dengan kriteria yang telah ditentukan. Penelitian ini dapat dijadikan sebagai pedoman dan acuan untuk penelitian sejenis dan selanjutnya. Penelitian ini juga diharapkan mampu memberikan bukti terkait dengan keefektifan model pembelajaran Problem Based Learning dan Problem Solving terhadap kemampuan berpikir kritis pada pembelajaran tematik siswa SD.

Penelitian ini memiliki keterbatasan temuan yaitu membutuhkan data berupa artikel-artikel yang sesuai dengan judul penelitian dan sesuai kriteria. Harus memiliki pengetahuan tentang cara memilih dan mengkomputasi effect size yang tepat dan menganalisis secara statistika. Kemudian terdapat bias pada pengambilan sampel dan publikasi. Bias pada pengambilan sampel disebabkan karena ketidakseragaman tiaptiap studi. Pada bias publikasi disebabkan karena data yang digunakan cenderung merupakan data yang telah terpublikasi yang biasanya datanya signifikan, sedangkan data yang tidak signifikan cenderung tidak dipublikasikan. Selanjutnya adanya kesalahan secara metodologi yakni adanya kesalahan dalam menentukan kesimpulan suatu studi dapat disebabkan karena kesalahan yang bersifat metodologi. Oleh karena itu, untuk mengatasi hal tersebut, sebaiknya menggunakan data dan statistik yang terdiri dari effect size, sample size, moderator variable, atau yang lainnya.

\section{KESIMPULAN}

Penelitian ini menggunakan jenis penelitian meta analisis. Pengumpulan data dilakukan melalui pencarian artikel-artikel di Google Cendekia. Berdasarkan analisis data dari 20 artikel, maka dapat disimpulkan bahwa model pembelajaran Problem Based Learning lebih efektif dibandingkan dengan menggunakan model pembelajaran Problem Solving untuk kemampuan berpikir kritis. Hal ini dapat dilihat 
1160 Efektivitas Model Pembelajaran Problem Based Learning dan Problem Solving terhadap Kemampuan Berpikir Kritis Siswa Sekolah Dasar - Oktavia Wahyu Ariyani, Tego Prasetyo

DOI : https://doi.org/10.31004/basicedu.v5i3.892

dari uji hipotesis menggunakan uji ancova yang menunjukkan $\mathrm{f}$ hitung $>\mathrm{f}$ tabel yaitu 3,462 > 3,20 dan signifikasinya $0,079>0,05$ yang berarti $\mathrm{H}_{\mathrm{o}}$ ditolak dan $\mathrm{H}_{\mathrm{a}}$ diterima, artinya terdapat perbedaan yang signifikan dalam menggunakan model pembelajaran Problem Based Learning dan Problem Solving dalam kemampuan berpikir kritis pada pembelajaran tematik siswa kelas IV SD. Hasil analisis Effect Size menggunakan uji ancova pada model pembelajaran Problem Based Learning dan Problem Solving diperoleh hasil Correct Model yang diketahui Partical eta Squared sebesar 0,161 dengan nilai signifikasi 0,079 yang berarti model pembelajaran Problem Based Learning dan Problem Solving memberikan pengaruh yang tergolong kecil. Uji Ancova dilakukan dengan menggunakan SPSS 24.00 for windows.

\section{DAFTAR PUSTAKA}

Amir. (2012). Inovasi Pendidikan melalui Problem Based Learning. Prenada Media Group.

Anastasia Nandhita. (2018). Penerapan model PBL untuk meningkatkan kemampuan berpikir kritis dan hasil belajar matematika siswa kelas 4 sd. JMP Online, 41 - 44.

Ayudya, M. S., \& Rahayu, T. S. (2020). Efektivitas Model Problem Based Learning Dan Think Pair Share Ditinjau Dari Kemampuan Berpikir Kritis Siswa Kelas 5 Dalam Pelajaran Matematika Dasar. Jurnal Pendidikan Tambusai, 4, 272-281. https://jptam.org/index.php/jptam/article/view/458

Elva Pristy Afifah, Wahyudi, Y. S. (2019). EFEKTIVITAS PROBLEM BASED LEARNING DAN PROBLEM SOLVING TERHADAP KEMAMPUAN BERPIKIR KRITIS SISWA KELAS V DALAM PEMBELAJARAN MATEMATIKA Universitas Kristen Satya Wacana PENDAHULUAN Kurikulum yang berlaku di Indonesia sekarang ini adalah kurikulum 2013 . Kur. Journal of Mathematics Education, Science and Technology, 4(1), 95-107.

Jensen. (2011). Pembelajaran Berbasis-Otak. Paradigma Pengajaran Baru.

Kadir. (2017). Meta-analysis of the Effect Learning Intervention Toward Mathematical Thinking on Reseach Publication of Student, Tarbiya. Journal of Education in Muslim Society.

Kemendikbud. (2016). Peraturan Menteri Pendidikan Nomor 22 Tahun 2016 tentang Standar Proses Pendidikan Dasar Dan Menengah.

Rusman. (2013). Faktor-faktor yang mempengaruhi hasil belajar. PT.Bumi Aksara.

Santrock. (2011). Perkembangan Anak Edisi 7 Jilid 2. (Terjemahan: Sarah Genis B. Erlangga.

Sapriya. (2011). Pendidikan IPS: Konsep dan Pembelajaran. PT.Bumi Aksara.

Sugiyono. (2010). Metode Penelitian Kuantitatif, Kualitatif dan R\&D. Alfabeta.

Suparman. (n.d.). Peningkatan Kemampuan Berpikir Kreatif Siswa Melalui Penerapan Model Problem Based Learning. Jurnal Bioedukasi. 3 (2) (2015): Halaman 367-372.

Tri Puji Ati, Y. S. (2020). Efektivitas Problem Based Learning-Problem Solving Terhadap Kemampuan Berpikir Kritis dalam Pembelajaran Matematika Siswa Kelas V. Jurnal Cendekia: Jurnal Pendidikan Matematika, 4(1), 294-303.Https://Doi.Org/10.31004/Cendekia.V4i1.209.

Utomo, D. (2013). Media Pembelajaran Aktif. Nuansa Cendekia.

Winoto, Y. C., \& Prasetyo, T. (2020). Efektivitas Model Problem Based Learning Dan Discovery Learning Terhadap Kemampuan Berpikir Kritis Siswa Sekolah Dasar. Jurnal Basicedu, 4(2), 228-238. https://doi.org/10.31004/basicedu.v4i2.348 